\title{
Discretionary fiscal spending needs to be raised further by allocating more towards MGNREGA
}

\author{
-- Shambhu Ghatak and Nabarun Sengupta ${ }^{1}$
}

International Monetary Fund's Fiscal Monitor report for October 2020 indicates that India's fiscal deficit as a proportion of gross domestic product (GDP) would rise from 6.3 percent in

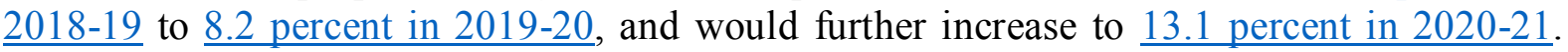
The widening of fiscal deficit as a proportion of GDP in India between 2019-20 and 2020-21 (i.e. by 4.9 percentage points) is broadly comparable to the average increase in fiscal deficit as a proportion of GDP observed among the emerging market and middle-income economies (i.e. by 5.8 percentage points). On the contrary, the fiscal deficit (combined) as a proportion of GDP for the advanced economies is expected to grow from 3.3 percent to 14.4 percent between 2019-20 and 2020-21 (i.e. by 11.1 percentage points). Thus, India's fiscal response has been weaker in comparison to that of the advanced economies till 11 September, 2020.

However, there is a similarity between India and advanced economies (such as Spain) in terms of the composition of fiscal response. Till 11 September, 2020, the discretionary fiscal stimulus in India has been just 1.8 percent of the GDP, which is a little over one-third of the total fiscal expansion. So, the fiscal deficit as proportion of GDP in India has arisen more on account of fall in tax collection and other types of automatic stabilizers (i.e. revenue and some expenditure items that adjust automatically to cyclical changes in the economy - for example, as output falls, revenue collections decline and unemployment benefits increase, which "automatically" provides demand support), and less due to a rise in the discretionary spending by the government. Government inaction, on the other hand, was hardly noted in the emerging market economies in comparison to India and around 60 percent of the fiscal expansion was on account of discretionary policy.

Aside from looking at fiscal response measure through the automatic cyclical responsediscretionary fiscal response lens, one can analyse fiscal response measures by the government from the point of view of traditional "above the line" measures versus liquidity support from "below the line" measures as well as contingent liabilities. The "below the line" measures include various forms of liquidity support, including equity injections, asset purchases, loans, and credit guarantees.

As of 11 th September, 2020, "below the line" liquidity support amounting to 5.2 percent of GDP exceeded discretionary fiscal spending (i.e. "above the line" measures) of 1.8 percent of GDP. However, for the emerging market and middle-income economies as a whole, the discretionary fiscal spending as a proportion of GDP has been greater than that of "below the line" measures like equity injections, loans, asset purchase, debt assumptions or guarantees.

\footnotetext{
${ }^{1}$ Nabarun Sengupta is doing his MA in Development Studies (2nd year) from Tata Institute of Social Sciences, Hyderabad. Shambhu Ghatak is Senior Associate Fellow at Common Cause and coordinator of Inclusive Media for Change Project (www.im4change.org). A previous version of this article was co-authored by Nabarun Sengupta, Balu N Varadaraj and Shambhu Ghatak, and was published at https://bit.ly/38B9Jaz. Nabarun Sengupta and Balu N Varadaraj did their summer internship with Inclusive Media for Change in June-July 2020. This is a revised version of the article with MGNREGA data updated till December 2020-January 2021.
} 
So, till 11 September, 2020, the country has witnessed fiscal deficit as a proportion of GDP rising as a result of more automatic stabilizers in comparison to discretionary policy action, and also due to more indirect instead of direct fiscal response. Kindly, note here that spending on the Mahatma Gandhi Rural Employment Guarantee Act i.e. MGNREGA, among others, is part of discretionary spending of the government.

The first advance estimates of the national income for 2020-21, which was released by the National Statistical Office (NSO) recently, shows that the country would face year-on-year contraction in 'Private Final Consumption Expenditure' (at 2011-12 prices i.e. in real terms) by -9.5 percent during 2020-21. Total 'exports' (in real terms) would contract year-on-year by -8.3 percent during 2020-21. 'Gross Fixed Capital Formation' (GFCF) at 2011-12 prices would also shrink year-on-year by -14.5 percent for the current fiscal year. Therefore, with three of India's growth engines (i.e. domestic demand, exports and private investments) underperforming presently, increasing government expenditure (in real terms) remains our last option to boost growth from -7.7 percent GDP growth expected in 2020-21. The question, however, remains whether the government should spend for infrastructure development (which is capital-intensive in nature, and thus may not increase effective demand in the short-run), or for enhancing the purchasing power of the poor and the marginalised.

Although social activists and concerned economists demanded at least Rs. 1 lakh crore to be earmarked in favour of the MGNREGS, the Finance Minister in her budget speech on 1st February 2020 allocated only Rs.61,500 crore to it for the financial year 2020-21. As compared to the fund spent on MGNREGA in 2019-20 (i.e. revised estimate of $\underline{\text { Rs.71,001.81 }}$ crore), the amount set aside initially for the scheme in 2020-21 was around Rs.9,501.81 crore lesser.

About two months later, a nationwide COVID-19 lockdown was imposed, which was like a bolt from the blue for the majority of the population. The lockdown not only impacted economic activities in both the formal and informal sectors badly, it also choked the supply chains (please click here and here to know more). Following the sudden imposition of the lockdown on March 25th, 2020, reverse migration of informal and income-poor migrant workers to villages or native places from cities and urban areas became a common sight, especially during March-May. Hence, the call for MGNREGA's expansion became stronger so as to support rural livelihoods.

As a routine exercise, MGNREGA wages across the states/ UTs are revised annually just ahead of the new financial year i.e. in March. On March 23 ${ }^{\text {rd }}, 2020$ the average MGNREGA wage rate was raised by an average Rs. 20/- per day i.e. from Rs.182.1 in 2019-20 to Rs.202.5 in 2020-21 with effect from 1st April, 2020. The government, however, announced that the wage hike was a part of the relief package under the Prime Minister Garib Kalyan Yojana. The wage increase under MGNREGA was expected to provide an additional Rs.2,000 benefit to a worker annually, according to the government. It estimated that the enhancement in wage rates would economically benefit approximately $\underline{13.62 \text { crore families. }}$

Criticising the government, a press release by a civil society organisation NREGA Sangharsh Morcha dated 26th March, 2020, however, clarified that the Finance Minister's announcement of providing an average of Rs.2,000/- extra per household annually through the rural employment guarantee scheme was a misnomer. In fact, the wage rate increase, which was announced on 23rd March, 2020, is a regular adjustment against inflation that is 
made every year. That should not have been termed as an "additional resource" as Ms. Nirmala Sitharaman had mentioned. On top of that, the Central Government did not adhere to the constitutional norm of providing minimum wages to MGNREGA workers. Given that a large number of migrant workers trudged back to their native villages due to the lockdown, many more rural residents required work under MGNREGA in the financial year 2020-21. In such extraordinary circumstances, the number of days of permissible work per rural household should not have been limited to 100 days per year, said the press release by NREGA Sangharsh Morcha.

In May 2020, an additional amount of Rs.40,000 crore was earmarked for MGNREGA under the Atmanirbhar Bharat Abhiyaan to provide employment to needy workers during the difficult period that emerged as a result of the pandemic. A sum of Rs.28,000 crore was released straightaway to the states/ UTs, according to a government document dated 2nd June, 2020.

We would like to point here an instance of confusion among researchers and the general public arising out of official press releases pertaining to MGNREGA and Garib Kalyan Rojgar Abhiyaan. As on 12th November, 2020, Rs.73,504 crore has been released under MGNREGA and 251 crore person-days of employment have been generated, according to the presentation for Atmanirbhar Bharat Package 3.0. The presentation pertaining to Atmanirbhar Bharat Package 3.0 dated 12th November, 2020 says that an additional outlay of Rs. 10,000 crores will be made for PM Garib Kalyan Rozgar Yojana-PMGKRY (which was earlier termed as Garib Kalyan Rojgar Abhiyaan, and was distinct from MGNREGA) during 202021. The presentation dated 12th November, 2020 also indicates that PMGKRY effectively dovetails various schemes, including MGNREGA, Pradhan Mantri Gram Sadak Yojana (PMGSY), etc., thus extinguishing the erstwhile difference between MGNREGA and Garib Kalyan Rojgar Abhiyaan. It is not clear to the authors whether the additional outlay of Rs. 10,000 crores made for PMGKRY would be entirely spent on MGNREGA.

Various media sources (click here and here), however, indicate that the total MGNREGA allocation for 2020-21 was Rs. 1,01,500 crore. However, budget documents of the Union Budget 2021-22 show that the fund allocated for MGNREGA has been slashed from $\underline{\text { Rs. }}$

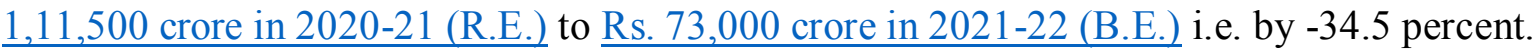

Data related to the status of MGNREGA in the present analysis has been accessed from 'At a Glance' and 'MIS Reports' sections of the scheme's official website.

\section{Approved labour budget and work actually generated}

The approved labour budget for MGNREGA was 220.67 crore person-days in 2014-2015, which expanded by almost 8.4 percent to reach 239.11 crore person-days in 2015-16. In 2018-19, this increased further to 256.56 crore person-days. In 2019-20, it increased by 8.2 percent compared to the previous year to 277.63 crore person-days. In 2020-21, approved labour budget rose by almost 20 percent compared to the previous year to 333.09 crore person-days (as on $5^{\text {th }}$ January, 2020). Please refer to chart-1. 


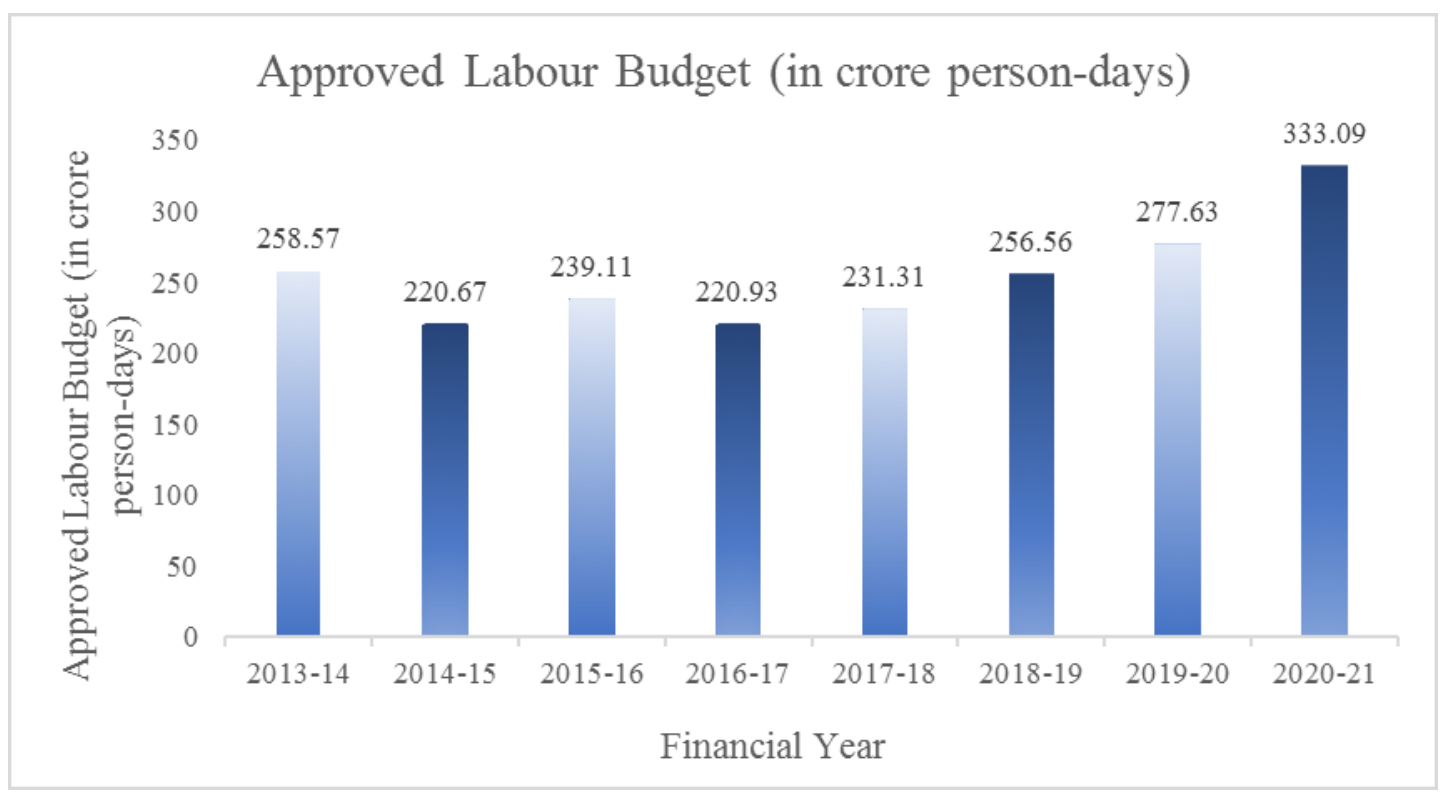

Source: "At a Glance” section of MGNREGA Website, please click here to access (Last accessed on $5^{\text {th }}$ January, 2021)

The approved labour budget in the beginning of the current financial year was estimated to be 280.76 crore person-days. However, with the additional infusion of Rs.40,000 crore into MGNREGA, the government expects that it will generate nearly 333.09 crore person-days of work in total (as per the approved labour budget for 2020-21).

It may be noted that labour budget under MGNREGA refers to advanced labour estimate for execution of a shelf of works for the next financial year. The advance assessment of labour demand in a district takes into account seasonality aspects along with the examination of employment and livelihood opportunities in the respective rural areas. On the basis of labour budget estimates, the Union Government projects its central liability towards the districts. For more information, please click here and here.

Given the fact that millions of unskilled migrant workers returned back to their villages/ native places from cities and urban areas following the implementation of COVID-19 lockdown, many demanded that the approved labour budget should have been further hiked to accommodate more of rural workers who demand MGNREGA jobs. Media reports suggest that most workers had chosen MGNREGA over Garib Kalyan Rojgar Abhiyaan since most of them were low-skilled or semi-skilled (please click here, here and here). Noted social activist Debmalya Nandy, who is associated with NREGA Sangharsh Morcha, said that the recently launched Garib Kalyan Rojgar Abhiyaan, which is expected to cover 116 high migrant "districts of six states", has received no additional budgetary allocation. The scheme is simply a convergence of 12 line departments/ ministries to execute existing asset generation programmes belonging to 25 public works categories. The government would have done better had the scheme been launched with adequate budgetary support in all rural districts of the country. It may seem that the scheme was launched to gain politically in Bihar elections.

In the current financial year, till $11^{\text {th }}$ January $2021,12.13$ crore persons demanded work under MGNREGA. However, in this period, the government could provide work only to around 10 crore persons. The first tracker by People's Action for Employment Guarantee 
(PAEG), released on 13th July, 2020, says that although employment generated in persondays is available easily in the MGNREGA's MIS database, work demanded in persondays is hardly available. Only the number of households demanding work and the number of individuals demanding work are available in the MGNREGA's MIS website. To know why it is important to have data on the persondays of work demanded, please consider this example. Suppose there are 3 individuals in a household. Suppose each person demands for seven days of work and each of them, however, receives three days of work. Let us assume for the time being that more than one person can be given work under MGNREGA from a single household. In the present example, the number of persons demanding work would be three and the number of individuals provided MGNREGA work would also be 3 . For the present case, the number of households demanding work would be one and number of households provided work would also be 1 . However, the number of persondays of work demanded is 21 while the number of persondays of employment provided is just nine. In this example, although employment provided in persondays is almost 57 percent lower than the work demanded in persondays, the MIS data would reflect that 100 percent of work demanded has already been met. Therefore, the persondays of work demanded must be made available along with the persondays of employment provided to track MGNREGA's progress more accurately.

The first tracker by People's Action for Employment Guarantee (PAEG), released on 13th July, 2020, also mentions that in the absence of having an alternative arrangement for registering demand for work, needy people will have no other choice but to rely on local officials to register work demand on the MIS. However, the concerned local officials may tend to limit the number of demands for work applications that are registered to avoid payment of unemployment allowance. Insufficient budgetary allocations by the Centre would thus limit registration in demand for work. Please note that unemployment compensation is paid to prospective workers, when registered demand for work is not met within 15 days.

It is interesting to note that in the case of West Bengal, which is heading towards legislative assembly elections in 2021 , the government provided work to around 1.08 crore individuals, out of 1.23 crore individuals that demanded employment.

As of 14th January, 2021, the average cost per day per person has been calculated at Rs.277.01 in 2020-21, which is significantly higher than that of 2019-20 (i.e. Rs.237.99) and 2018-19 (i.e. Rs.247.19). 


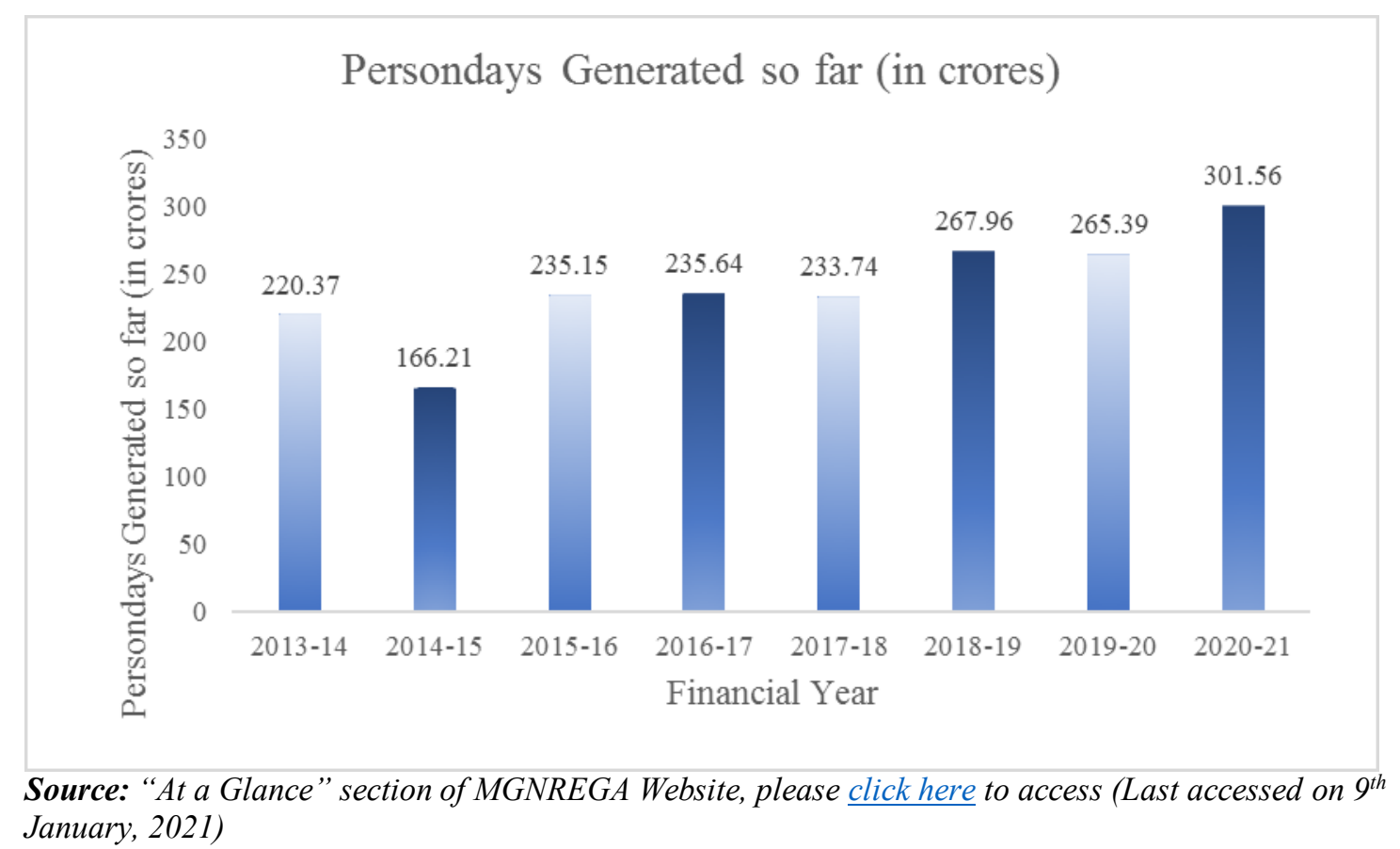

On comparing chart-1 against chart-2, it can be observed that against the approved labour budget of 256.56 crore person-days of work, the actual work generated was 267.96 crore person-days in 2018-19. The same trend has been observed (i.e. work provided being greater than approved labour budget) for 2016-2017 and 2017-18. Readers may note that demonetisation was implemented in the year 2016-17, which could have pushed up demand for MGNREGA jobs in rural areas in the absence of alternative work opportunities. The note ban severely affected the informal economy and the agrarian sector. For the financial year 2020-21, employment provided under MGNREGA is short of the approved labour budget limit by around 32 crore persondays, with still more than 2 and half months left in the current fiscal year (as per situation in mid-January 2021).

Up to December 2020, against the approved 294.7 crore persondays of work, 301.7 crore persondays of work was actually generated. In case of West Bengal, against the approved

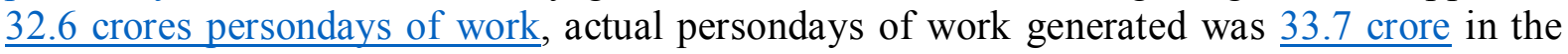
same time frame.

\section{Employment of the last resort for the poor and the marginalised}

There is a high demand for jobs under MGNREGA among rural persons belonging to Scheduled Tribes (STs) and Scheduled Caste (SCs) groups. It is because both income and non-income poverty is relatively higher among persons who are SCs or STs as compared to persons from general caste. Wages earned from MGNREGA helps in sustaining the livelihoods of the poor men and women who are eager to do unskilled manual work under the scheme.

Data from the official MGNREGA website shows that out of the total work created (in person-days) in the year 2014-15, 22.4 percent work went to SC workers. Over the years, this proportion decreased (with the exception of year 2017-18 when it saw a slight jump as 
compared to the previous year), and it finally reached 19.95 percent in 2019-20. Please check chart-3.

Chart 3: Work for SCs (in persondays) as a proportion of total work (in persondays), in \% SC Persondays \% as of total persondays

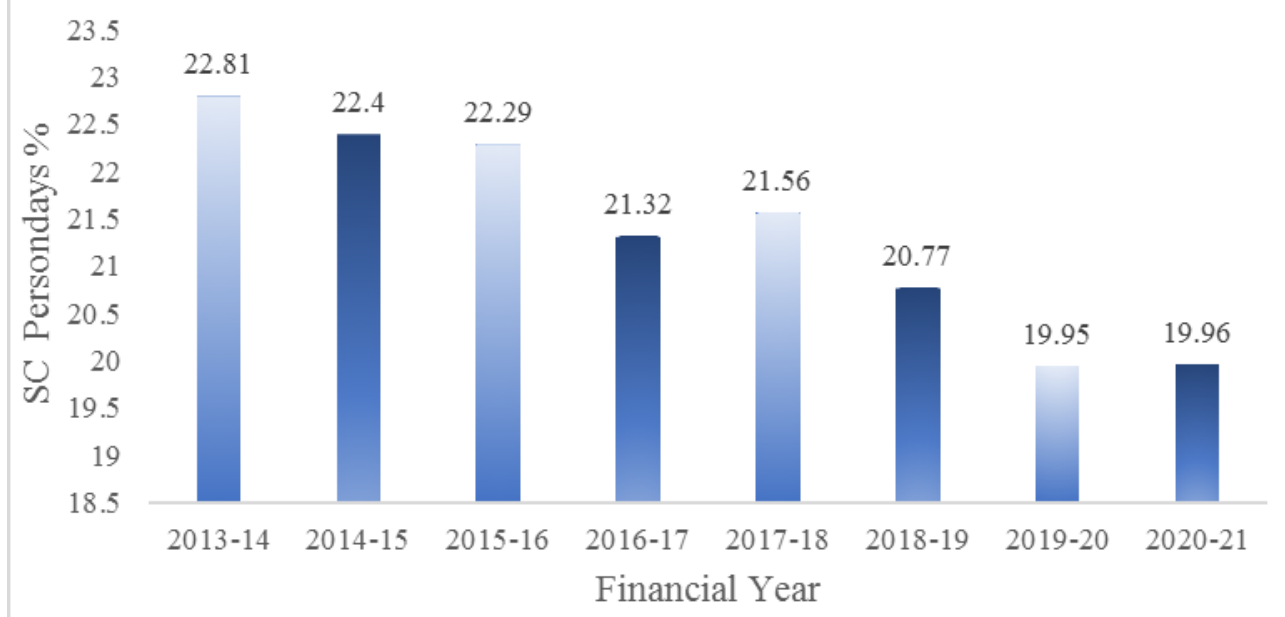

Source: "At a Glance" section of MGNREGA Website, please click here to access (Last accessed on $5^{\text {th }}$ January, 2021)

However, one finds a different trend in case of ST workers under MGNREGA from chart-4. Person-days of work created for ST workers as a proportion of the total work (in persondays) was almost 17 percent in 2014-15. This proportion increased to 17.8 percent in 2015-16. The figure was 17.4 percent in 2018-19 and 18.4 percent in 2019-20.

Chart 4: Work for STs (in persondays) as a proportion of total work (in persondays), in \%

ST Persondays \% out of total persondays

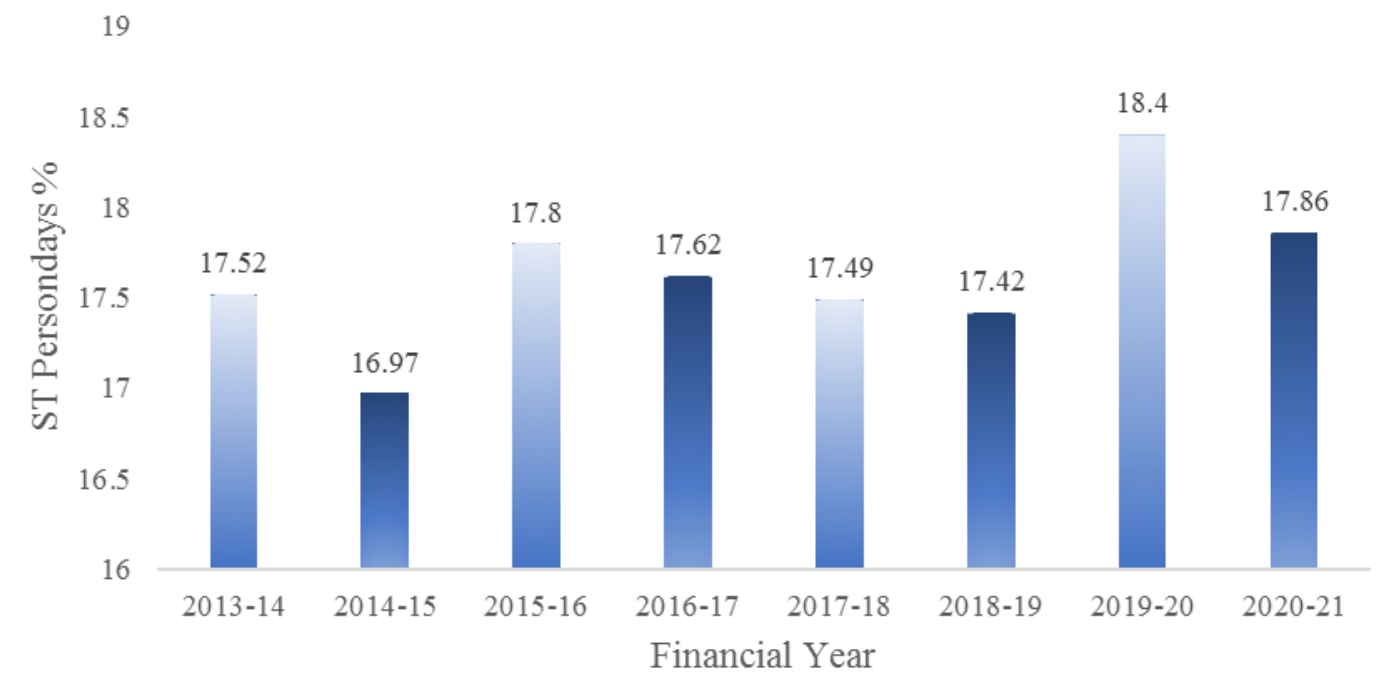

Source: "At a Glance" section of MGNREGA Website, please click here to access (Last accessed on $5^{\text {th }}$ January, 2021)

Out of the total work created (in persondays) in the year 2014-15, 54.9 percent work went to women workers. This proportion increased to 55.3 percent in 2015-16. In 2018-19, the 
related figure was 54.6 percent and it remained almost the same in 2019-20 i.e. 54.8 percent. Kindly consult chart-5.

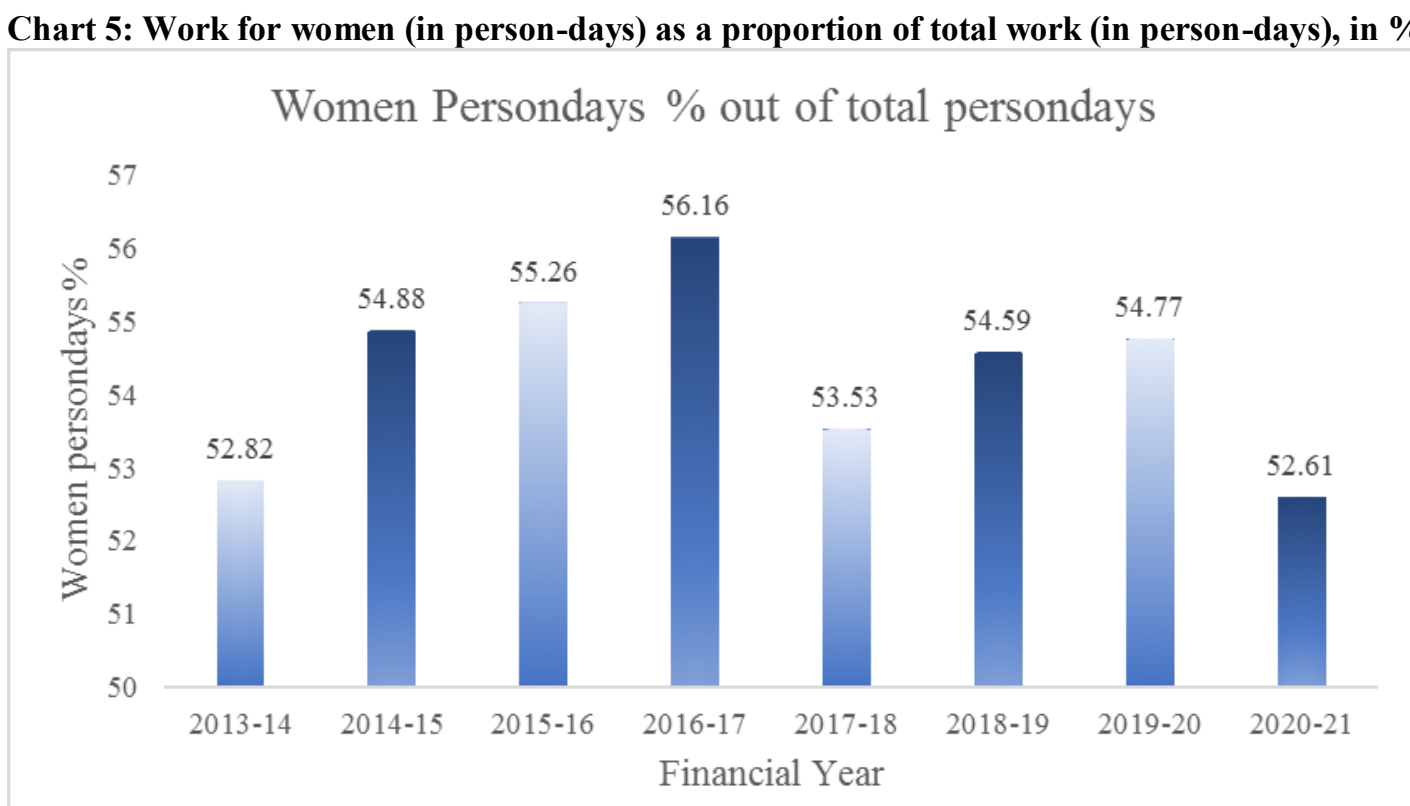

Source: "At a Glance" section of MGNREGA Website, please click here to access (Last accessed on $5^{\text {th }}$ January, 2021)

Calculations from the MIS database of MGNREGA show that for the current financial year, up to 11th January 2021, 19.9 percent of MGNREGA works have gone to people who are Scheduled Castes (SCs), 17.9 percent works have gone to people who are Scheduled Tribes (STs) and 52.7 percent of the works have gone to women.

Studies indicate that most of the informal sector activities are performed by SC and ST migrant workers, besides women workers. So, when the lockdown was imposed, it affected them the most and they left cities to return back to their villages/ native places. It is likely that most of the SC and ST male workers applied for MGNREGA work after reaching their villages. A number of recent studies (please click here and here) also indicate that the lockdown impacted women in a different way. Although their employment in paid work has reduced, the burden of unpaid care work, which they carry, has increased after the lockdown.

\section{Employment generated by MGNREGA}

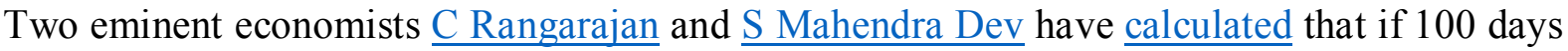
of guaranteed employment is given to 5.48 crore households in rural areas with a daily wage rate of Rs. 202.5 per person, then the total expenditure that should be ideally incurred by the government would be Rs. 1.44 lakh crores in the ongoing fiscal year. Presently, the MGNREGA provides around 50 days of employment in a year on an average, although the Act guarantees 100 days of employment. That is why the present allocation of Rs.1,01,500 crore for the scheme is inadequate. If the duration of guaranteed work is extended from 100 days to 150 days for 5.48 crore rural households under MGNREGA, then the government would have to spend Rs. 2.16 lakh crores in 2020-21. Please see the table below. 


\section{ESTIMATES OF EXPENDITUREFOR EMPLOYMENT GUARANTEE SCHEME INRURALANDURBAN AREAS (RSCRORE)}

\begin{tabular}{l|c|r|r|r}
\hline \multirow{2}{*}{$₹$} & \multicolumn{2}{|c|}{$\begin{array}{l}\text { Expenditure on Wages } \\
\text { (₹ Crores) }\end{array}$} & \multicolumn{2}{c}{$\begin{array}{c}\text { Expenditure on Wages and } \\
\text { Materials (₹Crores) }\end{array}$} \\
\cline { 2 - 5 } & 100 days & 150 days & 100 days & 150 days \\
\hline Rural & $1,10,970$ & $1,66,455$ & $1,44,261$ & $2,16,392$ \\
Urban & 53,865 & 80,798 & 70,025 & $1,05,037$ \\
Total & $16,48,35$ & $2,47,253$ & $2,14,286$ & $3,21,429$ \\
\% of GDP & $0.81 \%$ & $1.21 \%$ & $1.05 \%$ & $1.58 \%$
\end{tabular}

Note: According to Second Advanced Estimates of National Statistical Office,

Nominal GDP in 2019-20 is Rs. 203,84,759 crores.

Source: A safety net, post Covid: We need to provide minimum income for poor and vulnerable -C Rangarajan and S Mahendra Dev, The Indian Express, 3rd July, 2020, please click here to access

Critics of MGNREGA often argue that the scheme has failed to provide 100 days of employment to most unskilled manual workers who applied for work. However, nonpayment of MGNREGA wages on time to workers and meagerly revision of daily wage rates annually, among other things, have kept the poor away from the scheme in many states. It is worth noting that in January 2009, the Government of India issued a notification under Section 6(1) of the MGNREGA, which delinked MGNREGA wages from the Minimum Wage Act freezing MGNREGA wages at the prevailing state minimum wage or up to Rs. 100 per day. At present, MGNREGA wage rates in many states/ UTs are not only below the market wage rates, but also below the minimum wage rates for unskilled agricultural labourers.

The average days of employment provided per household stood dismally low at 40.17 in 2014-15. This increased significantly to 48.85 days in 2015-16 i.e. an increase by around 21.6 percent. In 2018-19 this figure touched 50.88 days. In 2019-20 the average days of employment dipped marginally to 48.39 days. In the pandemic struck year 2020-21, when the average days of employment under MGNREGA should have been significantly higher to cater to the poor people who are devoid of other sources of income, this figure was as low as 43.55 days (till 5 th January 2021). Please refer to chart-6. 
Chart 6: Average Days of Employment Per Household

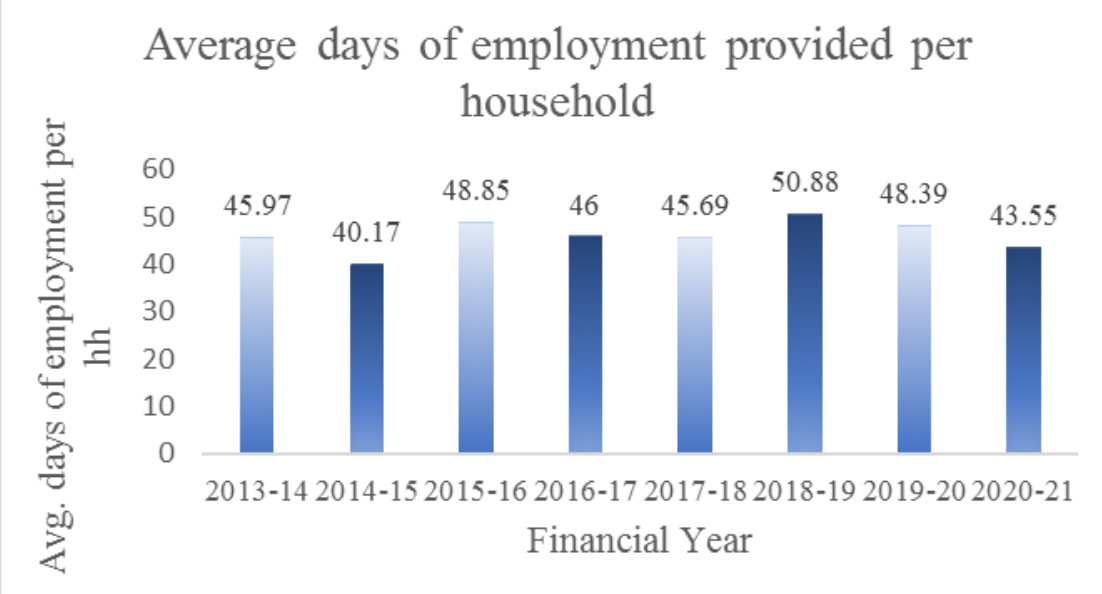

Source: "At a Glance" section of MGNREGA Website, please click here to access (Last accessed on $5^{\text {th }}$ January, 2021)

The proportion of households that completed 100 days of work under MGNREGA in 201415 was only 6 percent. This proportion increased to around 10.1 percent in 2015-16. In 201819 , this proportion stood at around 9.98 percent, but it fell to 7.4 percent in 2019-20.

As per MIS data, only 4.07 percent of households have been provided with 100 days of employment till $11^{\text {th }}$ January in the current fiscal year, with hardly three more months left for the year to end.

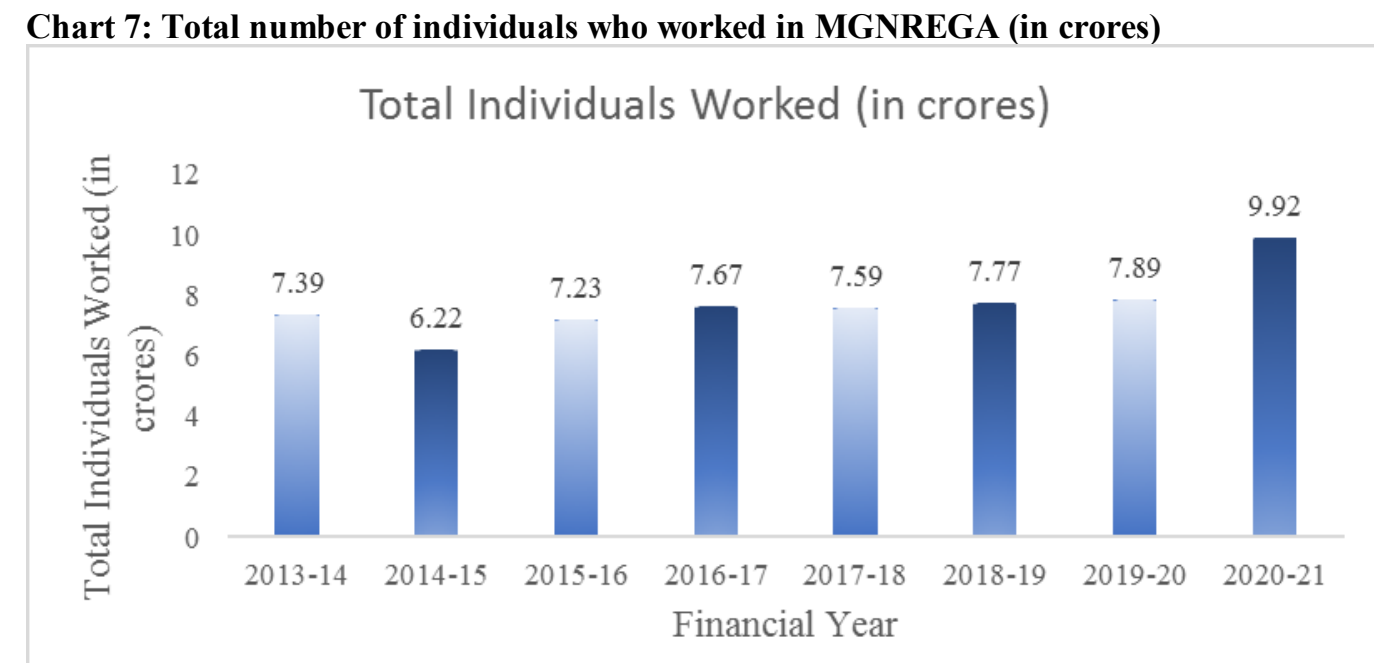

Source: "At a Glance" section of MGNREGA Website, please click here to access (Last accessed on $5^{\text {th }}$ January, 2021)

A total of 6.22 crore individuals worked under MGNREGA in 2014-15. This figure rose to 7.23 crores in 2015-16, an increase by around 16 percent. In 2018-19 and 2019-20, 7.77 crore and 7.89 crore individuals worked under MGNREGA, respectively. In 2020-21, the total number of individuals under MGNREGA increased to 9.92 crores. This was a massive increase by around 26 percent when compared to the previous year. Please consult chart- 7 .

During April-June 2020, employment provided by MGNREGA was 125.6 crore persondays. However, in the corresponding period in 2019-20, employment provided by MGNREGA was 96.5 crore persondays. Hence, employment under MGNREGA has seen a hike of 29.1 crore 
person-days between April-June 2019 and April-June 2020. This happened despite the fact that the government allowed MGNREGA work only from April 20th, roughly a month after the COVID-19 lockdown was imposed, and released funds for it tardily, as per the revised lockdown guidelines.

The average wage rate per person per day stood at Rs.143.92 in 2014-15. This increased by around 7.1 percent to Rs. 154.08 in 2015-16. In 2018-19, the average wage rate per person per day was Rs. 179.13, which increased marginally to Rs.182.09 in 2019-20. In 2020, the average wage rate per person per day increased to Rs.200.3, an increase of around 10 percent when compared to the previous year. Please check chart-8.

Chart 8: Average wage rate per day per person (in Rs.)

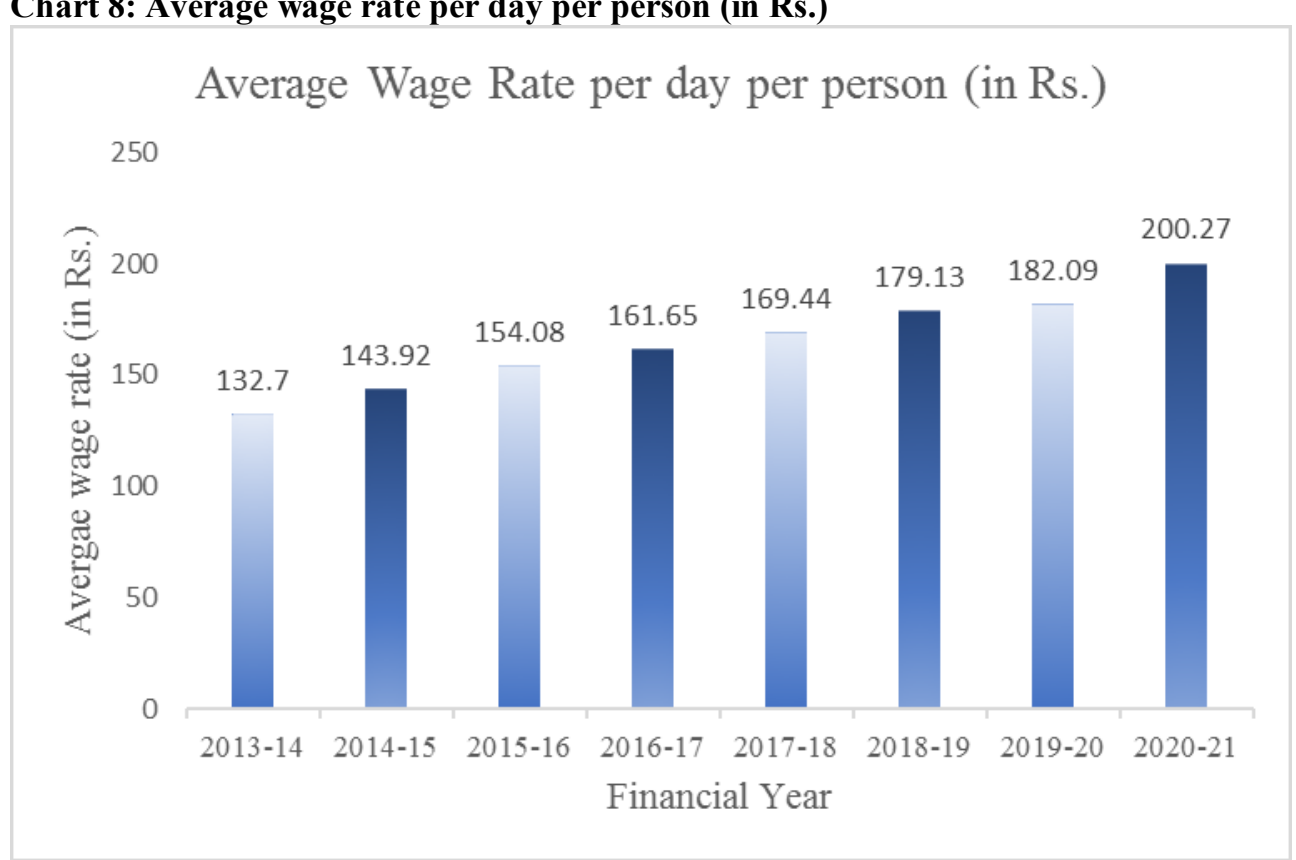

Source: "At a Glance" section of MGNREGA Website, please click here to access (Last accessed on $5^{\text {th }}$ January, 2021)

The Annual Report on Period Labour Force Survey 2017-18 had found that the average daily wage earnings (in rural areas) by casual labour engaged in works other than public works ranged between Rs.253 to Rs.282 among males and roughly Rs.166 to Rs.179 among females during July-September 2017, October-December 2017, January-March 2018 and April-June 2018. As against that, the average daily wage earnings by casual labour engaged in MGNREG public works in rural areas ranged between Rs.141 to Rs.171 among males and nearly Rs.131 to Rs.165 among females during July-September 2017, October-December 2017, January-March 2018 and April-June 2018.

Seeing the massive influx of returnee migrants in villages from cities, MGNREGA workers recently demanded a daily wage rate of at least Rs. 600 per person, besides 200 days of employment and stricter implementation of locally planned works. 


\section{Gram panchayats incurring no expenditure}

In 2014-15, there were 39,531 such gram panchayats, which incurred zero MGNREGA expenditure. In 2015-16, the number of such gram panchayats was 39,469. The number of gram panchayats which incurred zero expenditure were 10,978 in 2018-19 and 10,582 in 2019-20. In the current financial year, this number stands at 7,984 till $5^{\text {th }}$ January 2021. Please consult chart-9.

\section{Chart 9: Total number of gram panchayats with nil expenditure}

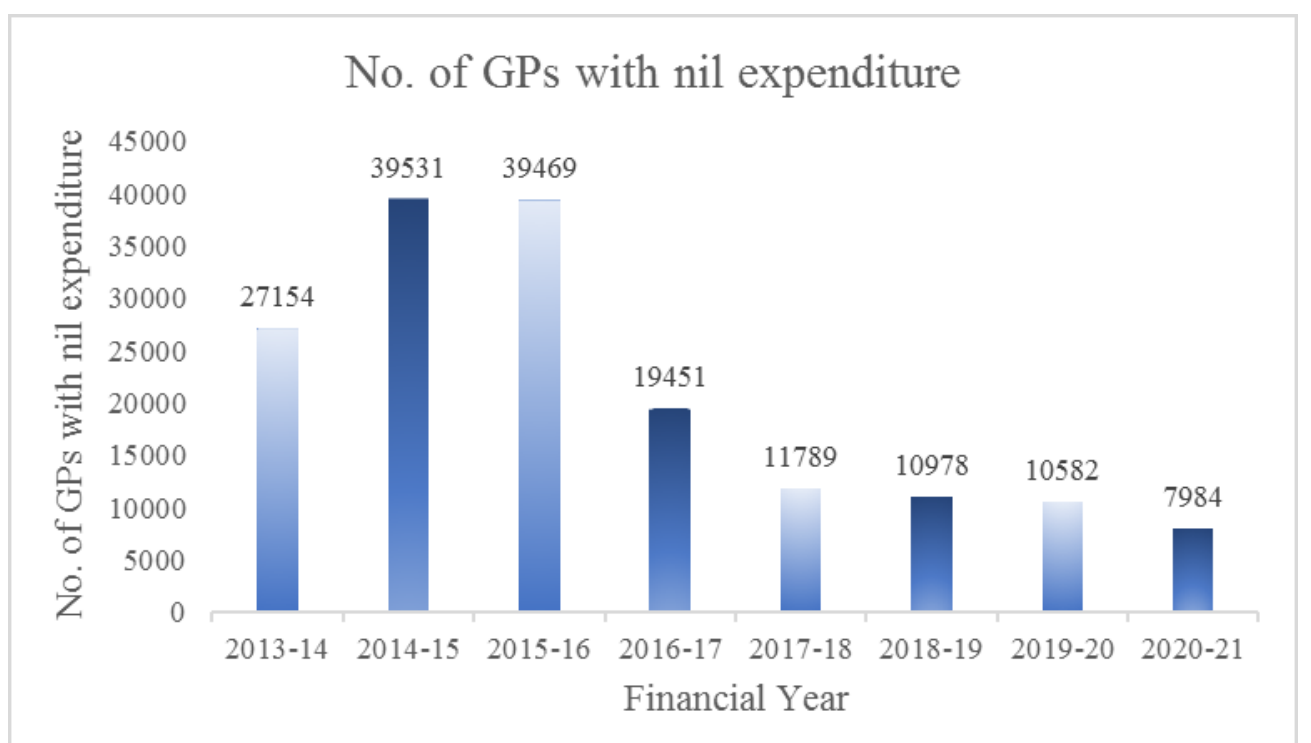

Source: "At a Glance" section of MGNREGA Website, please click here to access (Last accessed on $5^{\text {th }}$ January, 2021)

It may be added here that the total number of Gram Panchayats (GPs) that did not enter 'labour projection' is 34,149 in the ongoing financial year, which is 12.9 percent of total GPs, as on 17th January 2021. The total number of GPs that did not enter 'work projection' is 29,552 in the ongoing financial year, which is 11.2 percent of total GPs, as on 17th January, 2021. In GPs that did not enter labour projection and/or work projection, expenditure on MGNREGA is likely to be lesser.

\section{Various works performed under MGNREGA}

The total number of completed works as a proportion of total number of works taken up was 30.1 percent in 2014-15. In 2015-16, this figure was 29.4 percent. In the 2018-19, the total number of completed works as a proportion of total number of works taken up was 45.8 percent. In 2019-20 the related figure went down to around 39 percent. Please consult chart10 and chart-11. 


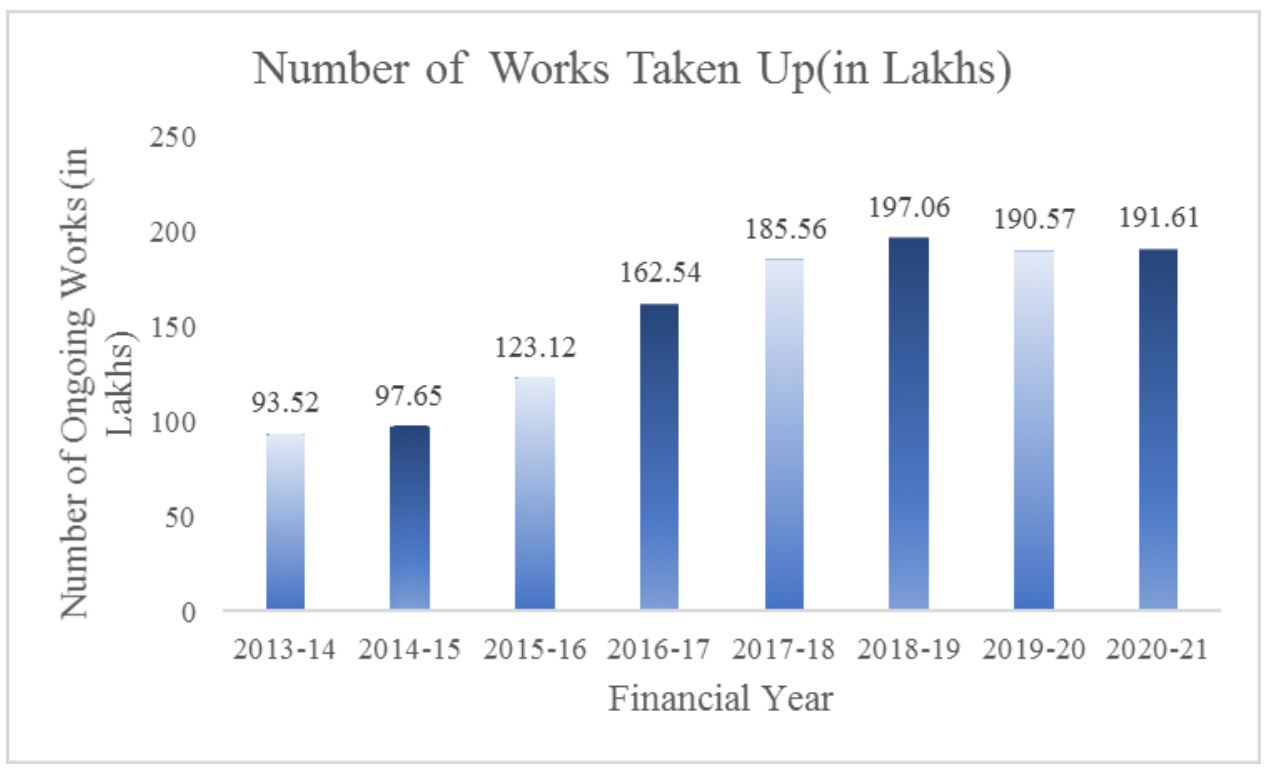

Source: "At a Glance" section of MGNREGA Website, please click here to access (Last accessed on $11^{\text {th }}$ January, 2021)

For the current financial year, total number of completed works as a proportion of total number of works taken up stands at 33 percent till $11^{\text {th }}$ January, 2021.

Chart 11: Number of Completed Works under MGNREGA

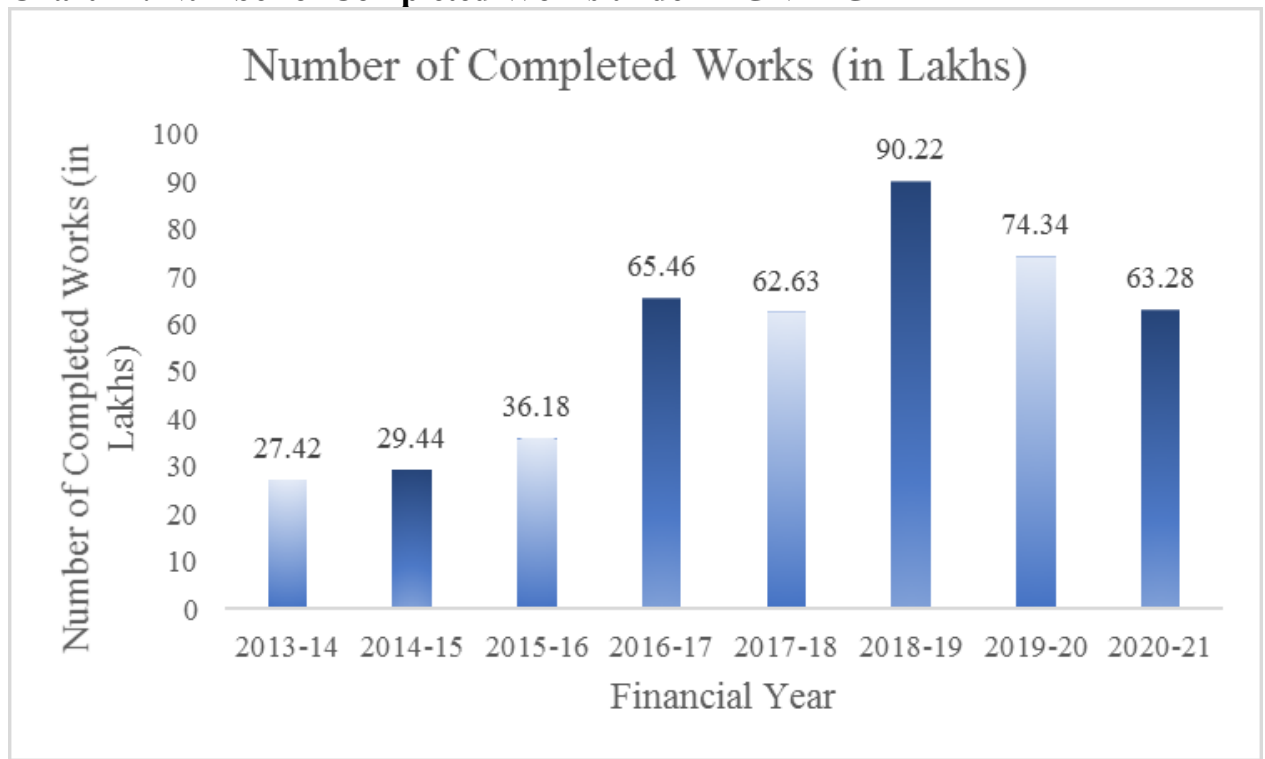

Source: "At a Glance" section of MGNREGA Website, please click here to access (Last accessed on $11^{\text {th }}$ January, 2021)

As per https://vikaspedia.in, works under MGNREGA can be classified mainly into:

1. Category A: Public Works Relating to Natural Resources Management;

2. Category B: Individual Assets for Vulnerable Sections (Only for Households in Paragraph 5 of Schedule I);

3. Category C: Common Infrastructure for DAY -NRLM Compliant Self-Help Groups; 
4. Category D: Rural Infrastructure; and

5. Individual farmer's land.

The share of expenditure on works related to natural resource management-NRM (i.e. Category A) in total MGNREGA spending was 55.4 percent in 2014-15, which increased to 59.7 percent in 2015-16. In 2018-19, this figure stood at 58.8 percent and in 2019-20, it was 61.9 percent. In the current financial year, the share of expenditure on works related to NRM in total MGNREGA spending is almost 68 percent, as on 11th January, 2021. Kindly refer to chart-12.

Chart 12: Proportion of expenditure on NRM Works (Category A)

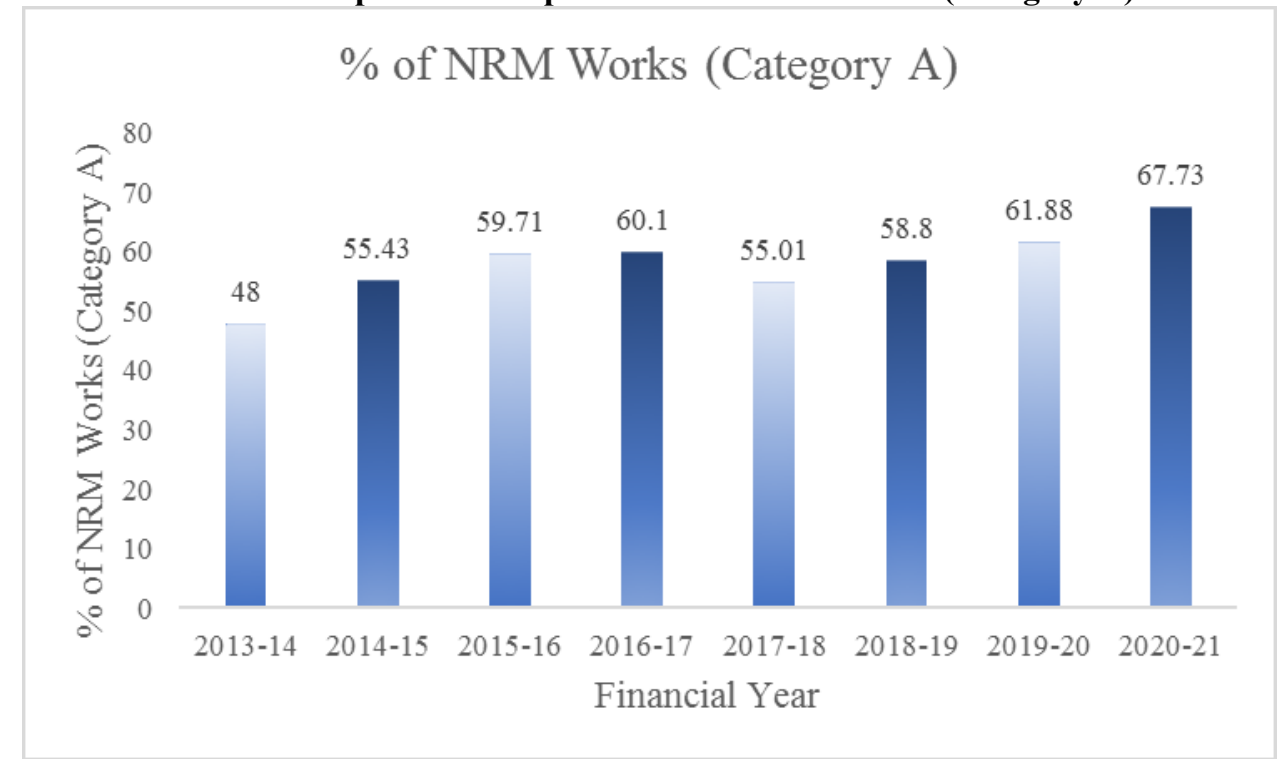

Source: "At a Glance" section of MGNREGA Website, please click here to access (Last accessed on $11^{\text {th }}$ January, 2021)

'Category A' work can help in protecting vulnerable and marginalised communities from droughts and rainfall deficit. They include the following:

* Water conservation and water harvesting structures to augment and improve groundwater like underground dykes, earthen dams, stop dams, check dams with special focus on recharging groundwater including drinking water sources;

* Watershed management works such as contour trenches, terracing, contour bunds, boulder checks, gabion structures and spring shed development resulting in a comprehensive treatment of a watershed;

* Micro and minor irrigation works and creation, renovation and maintenance of irrigation canals and drains;

* Renovation of traditional water bodies including desilting of irrigation tanks and other water bodies;

* Afforestation, tree plantation and horticulture in common and forest lands, road margins, canal bunds, tank foreshores and coastal belts duly providing right to usufruct to the households covered in Paragraph 5; and

* Land development works in common land.

The share of works related to individual assets for vulnerable sections (i.e. Category B) in total MGNREGA works was 21.4 percent in 2014-15, which increased to 33.8 percent in 2015-16. In 2018-19, this figure stood at 67.6 percent and in 2019-20, it was almost 67.4 
percent. In the current financial year, the share of works related to 'Category B' in total MGNREGA works is around 62 percent, as on 11th January, 2021. Kindly see chart-13.

Chart 13: Percentage of Category B works

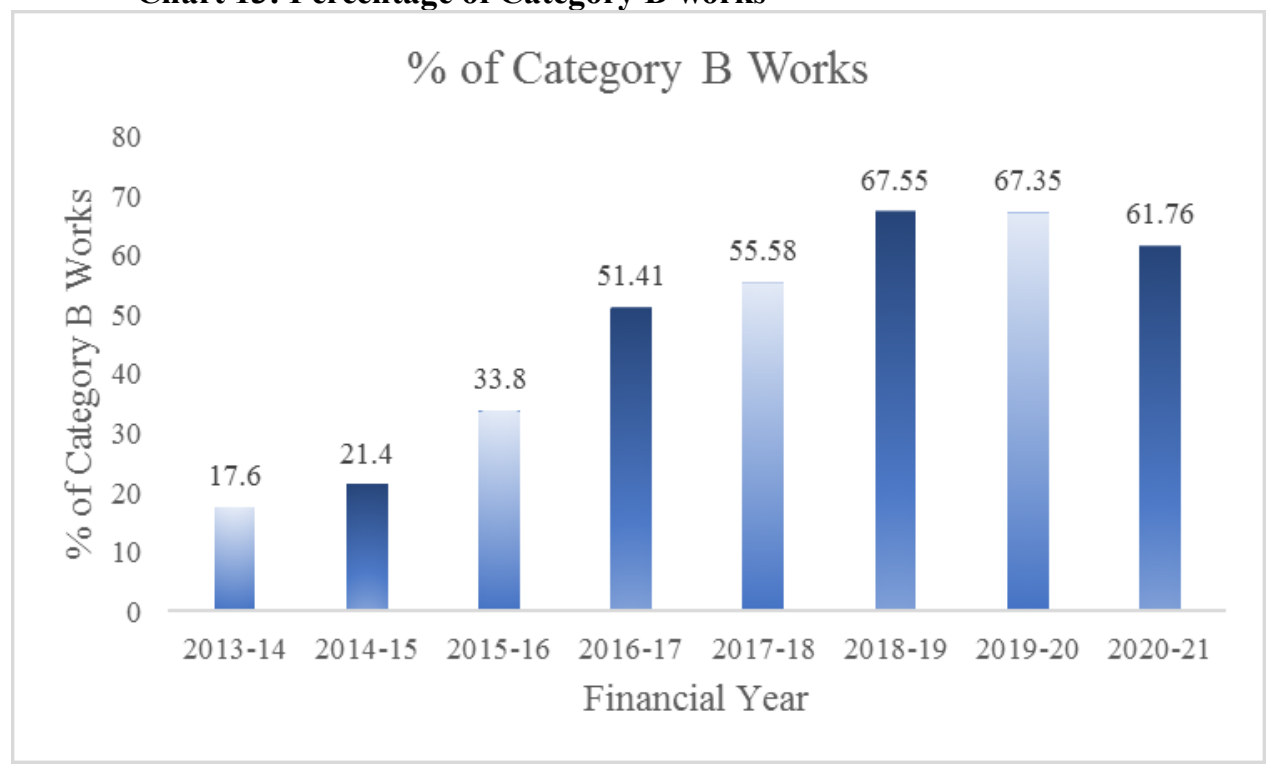

Source: "At a Glance" section of MGNREGA Website, please click here to access (Last accessed on $11^{\text {th }}$ January, 2021)

The share of expenditure on works related to agriculture and allied activities in total MGNREGA spending was 52.8 percent in 2014-15, which increased to 62.9 percent in 2015 16. In 2018-19, this figure stood at 63.4 percent and in 2019-20, it was 66.13 percent. In the current financial year, the share of expenditure on works related to agriculture and allied activities in total MGNREGA spending is 68.61 percent, as on 11th January, 2021. Please consult chart-14.

Chart 14: Percentage Expenditure on Agriculture and Allied Activities

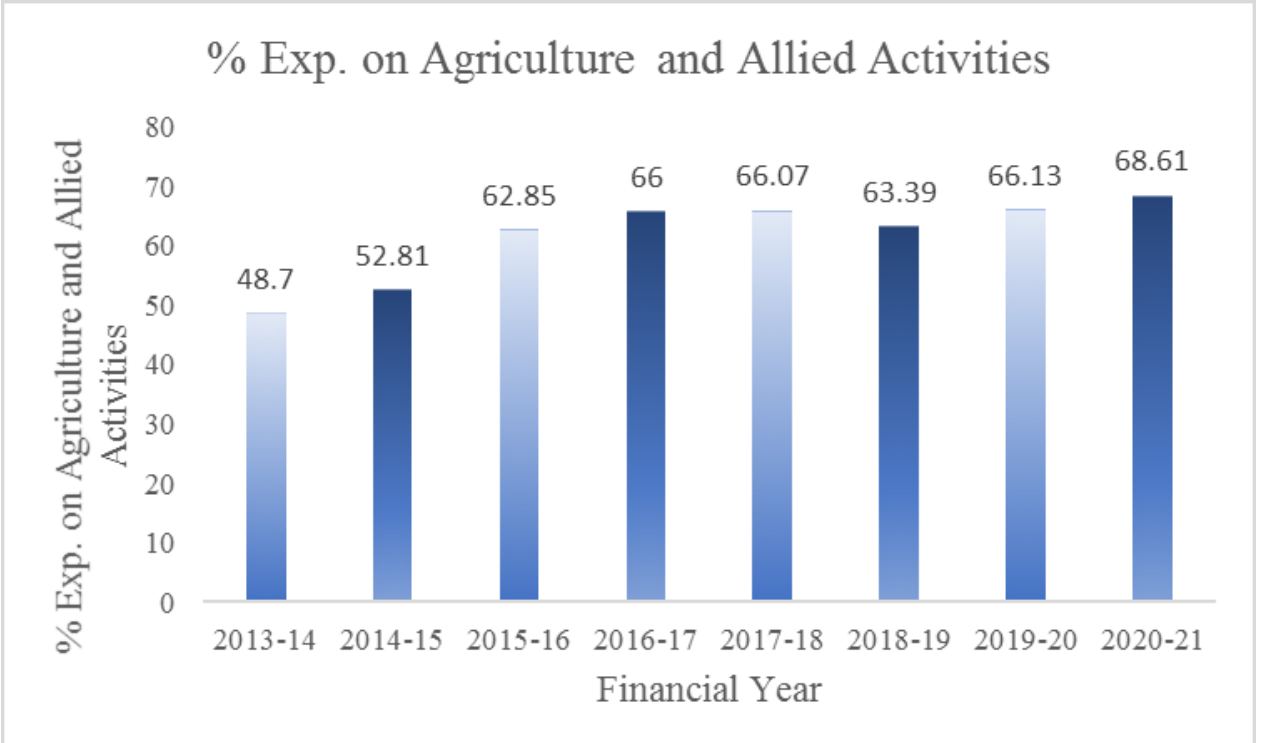

Source: "At a Glance" section of MGNREGA Website, please click here to access (Last accessed on 11 January, 2021) 


\section{Conclusion}

Data provided by the Centre for Monitoring Indian Economy (CMIE) shows that there has been a steep rise in unemployment rate from 6.5 percent noted in November 2020 to 9.1 percent in December 2020. The rise in unemployment rate in December in comparison to November was found in both urban and rural areas. The number of people employed in November and December 2020 was much lower than that in the corresponding period in 2019-20 as well as 2018-19. So, budgetary allocation for MGNREGA needs to be enhanced to provide more purchasing power in the hands of the poor and the marginalised. Aside from MGNREGA, urban employment programme should be launched, which can create employment in urban areas and address the precarity of the urban poor. As pointed out by experts, delays and failures in payment of pending MGNREGA wages needs to be checked.

\section{References}

Press Note on First Advance Estimates of National Income 2020-21, released on 7 January, 2021, National Statistical Office (NSO), Ministry of Statistics and Programme Implementation (MoSPI), please click here to read more

Presentation on Atmanirbhar Bharat Package 3.0 that was made by the Union Finance \& Corporate Affairs Minister Smt. Nirmala Sitharaman, dated 12th November 2020, please click here to access

Press note: Prime Minister Narendra Modi launches Garib Kalyan Rojgar Abhiyaan on 20th June 2020 to boost employment and livelihood opportunities for migrant workers returning to villages, in the wake of COVID-19 outbreak, Prime Minister's Office, Press Information Bureau, dated 20th June, 2020, please click here to access

Press note: All-time high amount of Rs. 61,500 crore allocated under MGNREGA for the FY 2020-21; Additional provision of Rs. 40,000 crore made for this programme under Atmanirbhar Bharat Abhiyaan to provide employment during the difficult period arising of COVID-19, Ministry of Rural Development, Press Information Bureau, dated 2nd June, 2020, please click here to access

Press Release: Finance Minister announces Government Reforms and Enablers across Seven Sectors under Atmanirbhar Bharat Abhiyaan, Ministry of Finance, Press Information Bureau, dated 17th May, 2020, please click here to access

Press release: Finance Minister announces Rs 1.70 Lakh Crore relief package under Pradhan Mantri Garib KalyanYojana for the poor to help them fight the battle against Corona Virus, Ministry of Finance, Press Information Bureau, dated 26th March, 2020, please click here to access

State-wise wage rate for unskilled manual workers (i.e. MGNREGA workers), Ministry of Rural Development Gazette Notification, dated 23rd March, 2020, please click here to access

Budget Speech by the Finance Minister dated 1 st February 2020, please click here to access

Notes on Demands for Grants, 2020-2021, Department of Rural Development, Ministry of Rural Development, Budget Documents, Ministry of Finance, please click here to access 
Annual Report on Periodic Labour Force Survey (July 2017 - June 2018), National Statistical Office, released in May 2019, please click here to access

Household Consumer Expenditure Across Socio-Economic Groups. 2011-12, NSS $68^{\text {th }}$ Round, please click here to access

Data of Fiscal Monitor: Policies for the Recovery, IMF, October 2020, please click here to access

Fiscal Monitor: Policies for the Recovery, IMF, October 2020, please click here to access,

World Economic Outlook, October 2020: A Long and Difficult Ascent, IMF, October 2020, please click here to access

Revised lockdown guidelines for MGNREGA dated 15th April, 2020, Ministry of Rural Development, please click here to access

News alert: SWAN's third report outlines the perpetual plight of migrants in terms of food shortage, income insecurity and travel difficulties during lockdown, Inclusive Media for Change, Published on June 14th, 2020, please click here to access

News alert: Lockdown led to massive job losses, show early results of an ongoing telephonic survey, Inclusive Media for Change, Published on May 13th, 2020, please click here to access

News alert: MGNREGA allocation is way off the mark to uplift the rural economy $\&$ address economic downturn, say Right to Work activists, Inclusive Media for Change, Published on February 3rd, 2020, please click here to access

News alert: No change in MGNREGA wage rates observed between 2018-19 and 2019-20 for 4 states \& 2 UTs, Inclusive Media for Change, Published on April 16th, 2019, please click here to access

News alert: Country's non-income-based poverty level has fallen over the past 10 years, shows new report, Inclusive Media for Change, Published on October 30th, 2018, please click here to access

How India could spend its way out of the Great Recession -Nikita Kwatra and Pramit Bhattacharya, Livemint.com, 12 January, 2021, please click here to access

Budget 2021: Allocation For MGNREGA To Be Maintained At ₹ 1 Lakh Crore, Says CII, NDTV, 12 January, 2021, please click here to access

In rural India, over-reliance on digital technology has worsen financial exclusion -Rajendran Narayanan and Sakina Dhorajiwala, The Indian Express, 6 January, 2021, please click here to access

MGNREGA Work Availability Slows Sharply As Resource Crunch Hits -Pallavi Nahata, Bloomberg/Quint, 5 January, 2021, please click here to read more 
Unemployment rate in India, CMIE, https://unemploymentinindia.cmie.com/

Labour markets disappoint in December -Mahesh Vyas, CMIE, 4 January, 2021, please click here to read more

Video: Discussion on State of the Indian Economy, India International Centre, New Delhi, dated 18 December, 2020, please click here to access

A 'duet' for India's urban women -Jean Drèze, The Hindu, 8 December, 2020, please click here to access

A Normalization of WFH is unlikely to raise women's participation in the labour force Ashwini Deshpande, The Indian Express, dated 6 November 2020, please click here to access

The paradox of India's stimulus response to the covid-19 crisis -Niranjan Rajadhyaksha, Livemint.com, 21 October, 2020, please click here to access

First MGNREGA tracker by Peoples' Action for Employment Guarantee (PAEG), released on 13th July, 2020, please click here to access

COVID-19 rural crisis: Why MGNREGA needs a harder push -Debmalya Nandy, Down to Earth, 5th July, 2020, please click here to access

Reset rural job policies, recognise women's work -Madhura Swaminathan, The Hindu, 4th July, 2020, please click here to access

A safety net, post Covid: We need to provide minimum income for poor and vulnerable -C Rangarajan and S Mahendra Dev, The Indian Express, 3rd July, 2020, please click here to access

Utilise MGNREGA to the fullest capacity -Brinda Karat, The Hindu, 1 July, 2020, please click here to access

86 per cent jump in MGNREGA demand in districts most migrants returned to -Harikishan Sharma, The Indian Express, 29th June, 2020, please click here to access

Of UP govt's 1.25 crore jobs, over 1 crore went to MGNREGA and MSME sectors Maulshree Seth, The Indian Express, 27th June, 2020, please click here to access

Uttar Pradesh employed 57.13 lakh under MGNREGA, 'highest in country' -Maulshree Seth, The Indian Express, 16th June, 2020, please click here to access

How covid-19 locked out women from jobs -Rukmini S, Livemint.com, 11th June, 2020, please click here to access

How many migrant workers displaced? A range of estimates -Seema Chishti, The Indian Express, 8th June, 2020, please click here to access 
COVID-19 Lockdown: Impact on Agriculture and Rural Economy -Vikas Rawal, Manish Kumar, Ankur Verma and Jesim Pais, Society for Social and Economic Research Monograph 20/3, please click here and here to access

'Unlocking the Urban: Reimagining Migrant Lives in Cities Post-COVID 19', Aajeevika Bureau, released on 1st May, 2020, please click here to access

FM's announcement of Rs 1.7 lakh crore in the wake of COVID-19, is less than half of the Rs. 3.75 lakh crores required to fulfil the minimal "emergency measures", convey concerned citizens \& grassroots activists, Press releases by NREGA Sangharsh Morcha dated 26th March, 2020, please click here to access

Planning for works and preparation of labour budget, Vikaspedia, Please click here to access Labour Budget, Arthapedia, Please click here to access

Outlay on Major Schemes, Union Budget 2021-22, please click here to access 